\title{
LAKWERK IN HET RIJKSMUSEUM
}

Van 16 juni tot 17 augustus 2009 besteedt het Rijksmuseum in een kleine presentatie aandacht aan $17^{\mathrm{e}}$-eeuws lakwerk. Centraal staat een recent verworven Nederlands lakkistje. Het kistje vertelt in al haar bescheidenheid (het is nauwelijks $10 \mathrm{~cm}$. groot) een opmerkelijk verhaal over Japanse pracht en Hollandse inventiviteit in de $17^{\mathrm{e}}$ eeuw. ${ }^{1}$

\section{Japans en Nederlands lakwerk}

Lakwerk was een van de meest opvallende handelsproducten die Europa vanuit Azië bereikten. Het diepzwarte, exotische en zeer sterke materiaal werd in Europa een gewild luxeproduct. De aantrekkingskracht die lakwerk nog altijd heeft, wordt eens te meer getoond door de spectaculaire koffer in Namban-stijl die het Rijksmuseum onlangs verwierf (zie het bericht over de aanwinst elders in dit blad).

Al vroeg in de $17^{\mathrm{e}}$ eeuw komen we lakwerkobjecten tegen in boedelinventarissen van welgestelde burgers in steden als Amsterdam en Haarlem. Ook later in de eeuw bleef lakwerk aanwezig in het Nederlandse interieur. Een kabinet dat in de presentatie getoond wordt, getuigt hiervan. In het kabinet, dat rond 1690 in Nederland is vervaardigd, zijn namelijk panelen van Japans lakwerk verwerkt. Zowel het hout- als het lakwerk zijn recent gerestaureerd, waardoor het kabinet weer in volle glorie te bewonderen is.

\section{Willem Kick en zijn 'compagnie van lackwercken'}

Vanaf het moment dat het eerste lakwerk Europa bereikte, werden pogingen ondernomen om het bijzondere materiaal na te maken. De eerste Westerling die we bij naam kennen die zich hiermee bezig hield, was Willem Kick. Toen de Harderwijkse burgemeester Ernst Brinck aan het begin van de $17^{\mathrm{e}}$ eeuw Amsterdam bezocht, beschreef hij in zijn aantekeningen een bezoek aan een winkel waar het uithangteken 'Oost-Indie' hing. Hij zag er 'hoe sie alderly lackwerck maken nae die maniere van China, als buffets, betsteden, kisten, etc.' De winkel waar Brinck binnenstapte, was hoogstwaarschijnlijk het bedrijf van de Amsterdamse ondernemer Willem Kick. Nog vóór het eerste VOC-schip in 1610 uit Japan in Texel aankwam, had Kick al een octrooi aangevraagd bij de Staten-Generaal voor het vervaardigen van lakwerk in Aziatische stijl. Zijn imitatielakwerk werd zo gewild dat de Staten-Generaal met enige regelmaat producten bij hem bestelde, bedoeld voor diplomatieke geschenken, zoals aan de Turkse Sultan Achmed I in 1612. 


\section{Een lakkistje uit 1618}

Het kleine juwelenkistje dat het Rijksmuseum onlangs heeft verworven, kan worden toegeschreven aan deze Willem Kick. De decoraties van het kistje zijn duidelijk geïnspireerd op Japanse voorbeelden. Een aantal details vertellen ons echter dat het vervaardigd is voor een Nederlands huwelijk in 1618. Het kistje is voorzien van Nederlandse huwelijkssymbolen, een monogram en een datering. Hiermee is het het vroegste gedateerde object van Nederlands imitatielakwerk. De Nederlandse herkomst wordt bovendien ondersteund door een aantal Nederlandse $17^{\mathrm{e}}$-eeuwse schilderijen, waarop zeer vergelijkbare kistjes zijn afgebeeld en waarvan er één op de presentatie te zien is. De vroege datering van het kistje en het feit dat Kick de eerste (en officieel de enige) was die imitatielakwerk mocht produceren, maken een toeschrijving aan hem mogelijk.

De presentatie rond het verworven kistje werpt (op)nieuw licht op de figuur van Willem Kick en bovenal op de populariteit van Aziatisch en Europees lakwerk in Nederland aan het begin van de $17^{\mathrm{e}}$ eeuw.

\section{Noot}

1. Met dank aan R. Baarsen, aan wiens publicatie 'Kistjes van Kick?; Hollands lakwerk uit de vroege $17^{\text {de }}$ eeuw', Bulletin van het Rijksmuseum 56/1-2 (2008) deze informatie ontleend is. 